\title{
Altered quinidine disposition in a patient with chronic active hepatitis
}

\begin{abstract}
J. ROBERT POWELL*
Pharm.D.

Kenneth A. ConRad $\dagger$

M.D.

Summary

A 49-year-old female with chronic active hepatitis and ventricular ectopic activity was given i.v. 600 mg quinidine gluconate $(4 \cdot 4 \mathrm{mg} / \mathrm{kg})$. Quinidine plasma concentrations were analysed by high pressure liquid chromatography and plasma protein binding by equilibrium dialysis. The pharmacokinetic values were total body clearance $0 \cdot 11 \mathrm{l} / \mathrm{kg} / \mathrm{hr}$, elimination half-life $41.5 \mathrm{hr}$, volume of the central compartment $2.26 \mathrm{l} / \mathrm{kg}$, volume of distribution from the area under the curve $6.5 \mathrm{l} / \mathrm{kg}$, and $19 \%$ unbound in plasma. Based on the limited information available, quinidine dosing should be markedly decreased in patients with severe liver dysfunction.
\end{abstract}

\author{
ROBERT OKADA $\dagger$ \\ M.D.
}
THEODOR W. GUENTERT $\ddagger$
Ph.D.

\author{
SIDNEY RIEGELMAN $\ddagger$ \\ Ph.D.
}

*School of Pharmacy, University of North Carolina, Chapel Hill, NC; †The College of Medicine, University a Arizona, Tucson, and $\ddagger$ The School of Pharmacy, University of California at San Francisco, U.S.A.

\section{Introduction}

The clinician is presented with a difficult problem when the anti-arrhythmic drug quinidine must be administered to a patient with liver disease. Even though quinidine is known to be eliminated from the body principally by hepatic metabolism, disposition of the drug in liver failure has been observed in only one patient (Conrad, Molk, and Chidsey, 1977). In addition, changes in distribution and protein binding may have to be considered when dosing this drug (Perez-Mateo and Erill, 1977; Affrime and Reidenberg, 1975). The following report describes quinidine disposition in a patient with chronic hepatitis.

\section{Case report}

A 49-year-old Caucasian housewife was admitted to the Arizona Health Sciences Center in September 1977 for evaluation of jaundice. She had been in good health until July 1974 when she developed jaundice while taking spironolactone and hydro- chlorthiazide (Aldactazide ${ }^{\circledast}$ ). The jaundice reo solved when the medication was discontinued. She was then asymptomatic until July of 1977 , when she experienced malaise, anorexia and weakness, an\& developed jaundice, dark urine and acholic stools.

Initial measurements included: temperature $37.0^{\circ} \mathrm{C}$, weight $136 \mathrm{~kg}$, height $165 \mathrm{~cm}$, regular putserate of 80 beats/min, and a blood pressure of $130+560$ $\mathrm{mmHg}$. An acneiform rash involved the thighs, bo and chest. There was neither palmar erythema spider angiomas. The lungs were normal. Examin s ation of the heart was normal except for a sofō systolic ejection murmur heard best along the uppeõ left sternal border. The liver size, spleen size, and $B$ presence of ascites could not be determined because of the patient's obesity.

Initial laboratory data included (normal ranges in? brackets): blood urea which was 28 (9-20); and̄ serum creatinine $221 \mu \mathrm{mol} / 1$ (27-115). The SGOT was 181 i.u., SGPT 123 i.u., and alkaline phos-3. phatase 85 i.u./l (30-100). Total bilirubin was 385$\mu \mathrm{mol} / \mathrm{l}$ with a direct reacting component of $232 \cdot 6$. $\mu \mathrm{mol} / \mathrm{l}$. The prothrombin time was $27.9 \mathrm{sec}(11.5) .0$ A test for anti-nuclear antibody was positive at a dilution of 640 to 1 with a homogeneous pattern. She had a negative test for hepatitis-associated anti- $\rightarrow$ body. Serum electrophoresis demonstrated a totalo serum protein of $89 \mathrm{~g} / 1(60-80)$ with an albumin of $\mathrm{f}_{\mathrm{N}}$ $24 \mathrm{~g} / \mathrm{l}(35-50)$. There was an elevated polyclonalos gammaglobulin.

The patient was thought to have a chronic active $\mathrm{N}_{\mathrm{N}}$ hepatitis of immune aetiology. Abnormal clottingo parameters failed to improve to an extent sufficiento to allow percutaneous needle biopsy of the liver. $\frac{\mathrm{C}}{\mathbb{D}}$ A liver and spleen scan following the i.v. injection of? ${ }^{99 \mathrm{~m} T c}$ sulphur colloid demonstrated a normalo sized liver with patchy uptake and splenomegaly. 
On the sixth hospital day the patient experienced the sudden onset of palpitations followed by chest discomfort. An electrocardiogram demonstrated atrial fibrillation with a ventricular response between 140 and 160 beats/min with short episodes of probable ventricular tachycardia. The patient was given i.v. lignocaine and digoxin. The atrial fibrillațion reverted to normal sinus rhythm; however, considerable ventricular ectopic activity persisted despite a maximum lignocaine infusion rate. It was felt that another antiarrhythmic agent would be necessary to control the ectopy. She was therefore given an i.v. infusion of $600 \mathrm{mg}$ quinidine gluconate $(4.4 \mathrm{mg} / \mathrm{kg})$ in $100 \mathrm{ml} 5 \%$ dextrose in water over a 70-min period. Two physicians were in attendance and blood pressure was monitored every $5 \mathrm{~min}$. The serum quinidine level one $\mathrm{hr}$ after ending the infusion was only $0.4 \mu \mathrm{g} / \mathrm{ml}$. Therefore, a second infusion was given consisting of $1000 \mathrm{mg}$ quinidine gluconate $(7.35 \mathrm{mg} / \mathrm{kg})$ in $100 \mathrm{ml} 5 \%$ dextrose in water over a 60 -min period. Serum samples were obtained at frequent intervals following the end of the infusion

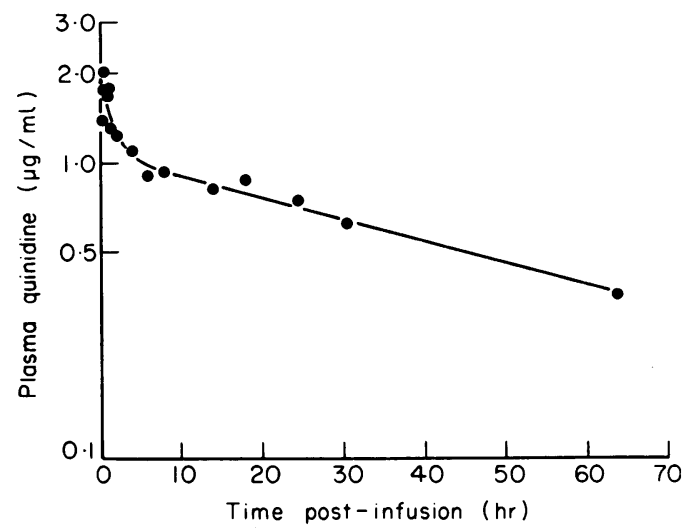

FIG. 1. Semi-logarithmic graph of plasma quinidine concentration decline following a one-hr infusion. The data points are actual and the curve is the computer-generated best fit.

over the subsequent $64 \mathrm{hr}$ (Fig. 1). Liver enzyme and bilirubin elevations were unchanged from admission values during this time. Since the patient did not experience subsequent arrhythmias, maintenance quinidine was not initiated.

\section{Materials and methods}

Quinidine plasma concentrations were analysed by a high pressure liquid chromatograph (Varian 8500) equipped with a silica column Micropak ${ }^{\circledR}$ $\mathrm{Si}-10)$ and a Varian variable wavelength u.v. detector set at $230 \mathrm{~nm}$. This procedure is sensitive to a quinidine plasma concentration of $20 \mathrm{ng} / \mathrm{ml}$ and has a coefficient of variation of $1.5 \%$. Protein binding was determined by equilibrium dialysis using $0.15 \mathrm{M}$ phosphate buffer at pH 7.4. The plasma sample taken $2.25 \mathrm{hr}$ after starting the quinidine infusion was used for protein binding analysis. According to preliminary experiments, equilibrium between the half-cells separated by a dialysis membrane (Dialyzing Cellulose, VWR Scientific Inc.) was complete after 2-3 hr, and all dialysis experiments were therefore carried out for $4 \mathrm{hr}$, at which time the concentration in both half-cells was determined.

The pharmacokinetic parameters were obtained by a non-linear least squares regression analysis of post-infusion plasma concentration (Metzler, 1969). The data were fitted to a 2-compartment model which makes allowance for the i.v. infusion and the pre-infusion quinidine concentration (Gibaldi and Perrier, 1975).

\section{Results}

The quinidine plasma concentration time curve is presented in Fig. 1. The pharmacokinetic parameters in this patient were total body clearance $0 \cdot 11 \mathrm{l} / \mathrm{kg} / \mathrm{hr}$, elimination half-life $41.5 \mathrm{hr}$, volume of the central compartment $\left(\mathrm{V}_{1}\right) 2 \cdot 26 \mathrm{l} / \mathrm{kg}$, volume of distribution from the area under the plasma concentration-time curve $\left(\mathrm{Vd}_{\text {area }}\right) 6.51 / \mathrm{kg}$, and $19 \%$ unbound (free) quinidine in plasma.

\section{Discussion}

The pharmacokinetic parameters of the patient are compared to those determined in other patients (Table 1). This patient's parameters are similar to those previously obtained from another patient (A.S.) with abnormal hepatic function (Conrad et al., 1977), but significantly different from 2 previous studies of 9 and 11 patients without hepatic disease respectively (Conrad et al., 1977; Ueda et al., 1976). The 2 patients with reduced hepatic function have prolonged quinidine half-lives, larger volumes of distribution and reduced total body clearance relative to the range of parameters in patients without liver disease. Both patients with liver disease also had decreased renal function. However, renal function may be expected to have only a slight influence on quinidine clearance since only 17 to $21 \%$ of a dose is eliminated unchanged in the urine. The observed half-lives of 41.5 and $53 \mathrm{hr}$ in these 2 patients must therefore be due to a significant reduction of quinidine liver metabolism rate and increase in the volume of distribution. Severe liver disease should be expected to decrease the clearance of quinidine as this condition decreases the clearance of other drugs which are primarily eliminated from the body by metabolism (e.g. theophylline, phenobarbitone, propranolol).

It is not conclusively known whether liver disease 
TABle 1. Quinidine disposition in patients with and without liver disease (mean \pm s.e. mean)

\begin{tabular}{|c|c|c|c|c|}
\hline \multirow[t]{2}{*}{$\begin{array}{l}\text { Pharmacokinetic } \\
\text { parameter }\end{array}$} & \multicolumn{2}{|c|}{$\begin{array}{l}\text { Patients without } \\
\text { liver disease }\end{array}$} & \multicolumn{2}{|c|}{$\begin{array}{l}\text { Patients with } \\
\text { liver disease }\end{array}$} \\
\hline & $\begin{array}{l}\text { Ueda et al. } \\
\qquad(1976) \\
n .=11\end{array}$ & $\begin{array}{c}\text { Conrad et al. } \\
\text { (1977) } \\
n .=9\end{array}$ & $\begin{array}{l}\text { Conrad } \\
\text { et al. } \\
\text { (1977) } \\
\text { (Subject } \\
\text { A.S.) }\end{array}$ & $\begin{array}{l}\text { This } \\
\text { study }\end{array}$ \\
\hline $\begin{array}{l}t_{1} \frac{1}{2} \beta(\mathrm{hr}) \\
\mathrm{V}_{1}(\mathrm{l} / \mathrm{kg}) \\
\mathrm{Vd}_{\text {area }}(1 / \mathrm{kg}) \\
\mathrm{Cl}_{\text {Total }}(\mathrm{l} / \mathrm{kg} / \mathrm{hr})\end{array}$ & $\begin{array}{l}6 \cdot 3(0 \cdot 5) \\
0.9(0 \cdot 1) \\
2 \cdot 4(0 \cdot 3) \\
0 \cdot 28(0 \cdot 03)\end{array}$ & $\begin{array}{l}7 \cdot 8(0 \cdot 7) \\
\quad- \\
3.0(0 \cdot 5) \\
0 \cdot 29(0.05)\end{array}$ & $\begin{array}{c}53 \\
-\overline{9 *} \\
0 \cdot 13\end{array}$ & $\begin{array}{l}41 \cdot 5 \\
2 \cdot 26 \\
6 \cdot 5^{*} \\
0 \cdot 11\end{array}$ \\
\hline
\end{tabular}

influences the fraction of free quinidine in plasma. Since it is generally believed that the pharmacological effects of most drugs are a function of the free drug plasma concentration rather than the total drug plasma concentration, a large increase in the free quinidine concentration may result in an exaggerated or 'toxic' response at doses or plasma drug concentrations generally associated with safety and efficacy. Plasma quinidine concentrations in these situations would be misleading since they measure total, not free, drug concentration. The per cent. free plasma quinidine is reported to be $14.1 \%$ in normal subjects and $41.5 \%$ in patients with liver disease (Affrime and Reidenberg, 1975), while others found the per cent. free to be $11 \%$ in normals and $19 \%$ in liver disease (Perez-Mateo and Erill, 1977), both using ultrafiltration techniques. The per cent. free quinidine in normal subjects has been reported to be much higher by other investigators using equilibrium dialysis [ $25 \%$ (Chien, Lambert and Karim, 1974; Woo and Greenblatt, 1978) and $29 \%$ (Kates, Sokoloski and Comstock, 1978)]. Similar studies in the present patient indicate a $19 \%$ free drug concentration, which raises the possibility that liver disease may not significantly influence quinidine protein binding. Additional studies are needed to clarify this apparent discrepancy.

Conclusive quinidine dosing recommendations in patients with liver failure certainly cannot be proposed based on the data from 2 patients. However, since the pharmacokinetic parameters were significantly and similarly different in the 2 cases from those found in normal subjects, it seems prudent to recommend a maintenance dosage reduction in patients with liver disease. Because of the larger volume of distribution, a larger loading dose may be required. Based on clearance alone in the 2 liver disease patients, the appropriate quinidine maintenance dose would have been one-half the usual quinidine daily dose $(14 \mathrm{mg} / \mathrm{kg} /$ day $)$. That is, 3.5 $\mathrm{mg} / \mathrm{kg}$ could be given every $12 \mathrm{hr}$ and would be expected to achieve an average quinid ine plasma con $\stackrel{0}{0}$ centration of $2-5 \mathrm{mg} / \mathrm{l}$. Whether this dose is appropriate for other patients with liver disease is yet to be determined. Plasma concentration deter-N

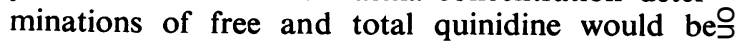
useful, but the ultimate guide will be to achieve the desired clinical response.

\section{Acknowledgments}

This work was supported in part by grant GM 16496-10 from the National Institute of General Medical Science Food and Drug Administration Contract 223-74-3145, a The Swiss National Science Foundation.

\section{References}

Affrime, M. \& Reidenberg, M.M. (1975) The protein binding of some drugs in plasma from patients with $\frac{\mathrm{D}}{\mathrm{D}}$ alcoholic liver disease. European Journal of Clinical Pharmacology, 8, 267.

Chien, Y.W., Lambert, H.J. \& Karim, A. (1974) Compara- $\frac{0}{3}$ tive binding of disopyramide phosphate and quinidine sulfate to human plasma proteins. Journal of Pharmaceutical Sciences, 63, 1877.

Conrad, K.A., Molk, B.L. \& Chidsey, C.A. (1977) Pharmacokinetic studies of quinidine in patients with arrhythmias. Circulation, 55, 1.

Gibaldi, M. \& Perrier, D. (1975) Pharmacokinetics, p. 69. $\frac{0}{3}$ Marcel Dekker, New York.

KaTES, R.E., SoKoloski, T.D. \& Comstock, J.F. (1978) Binding of quinidine to plasma proteins in normal subjects and in patients with hyperlipoproteinemias. Clinical Pharmacology and Therapeutics, 23, 30.

MetZler, C.M. (1969) NONLIN, a Computer Program for $D$ Parameter Estimation in Nonlinear Situations. The Upjohn Company, Kalamazoo.

Perez-Mateo, M. \& Erill, S. (1977) Protein binding of $\mathcal{N}$ salicylate and quinidine in plasma from patients with renal failure, chronic liver disease and chronic respiratory $\mathrm{N}$ insufficiency. European Journal of Clinical Pharmacology, $N$ $11,225$.

Ueda, C.T., Hirschfeld, D.S., ScheinmanN, M.M., Rowland, M., Williamson, B.J. \& Dzindzio, B.S. (1976) Disposition kinetics of quinidine. Clinical Pharma- $\frac{\bar{D}}{\mathrm{Q}}$ cology and Therapeutics, 19, 30.

Woo, E. \& GreenblatT, D.J. (1978) Pharmacokinetics and clinical effects of unbound quinidine in humans. (Abstract) Clinical Pharmacology and Therapeutics, 23, 136. 